\title{
LEADERSHIP CHALLENGES FOR PUBLIC RESEARCH UNIVERSITIES: THE PERSPECTIVE OF ONE LAND-GRANT INSTITUTION
}

\author{
Jon Wefald \\ President \\ Kansas State University
}

All Universities are in competition - we all know it and we can state it upfront. We compete for the brightest and the best faculty members. We compete for the sharpest and the most insightful students - the ones who can challenge the faculty members to think in new and unique ways. And we compete for the resources that keep the financial blood flowing in our research and educational programs. Just as "location, location, location" is the business mantra, "Grants, Gifts, and Tuition" is the chant of the research university president.

Dr. Freeman in her talk gave us a faculty perspective on this issue. She emphasized the increasing role that Centers and Institutes are playing in campus research life. Centers and Institutes are not only changing some of the ways that we conduct and administer our research, but they also are helping us in our quest to be successful in a competitive marketplace. By creating these centers, we are building teams of faculty members - collaborations that help us attract and keep our best faculty. We want the team to be strong - so strong that the brightest young faculty are attracted and want to join. We want the team to be so strong, that should a faculty member decide to leave, they would be leaving an essential part of them. In short, they would be leaving their best, creative ideas back in Manhattan.

Teams are tools for recruiting and retaining the best faculty members, and they are also tools for recruiting the sharpest and most insightful students, as the opportunities for student involvement within the teams grow. We want the teams to be strong, so strong that they attract the attention of the funding agencies. And, in terms of the quest for dollars to support the University infrastructure, these funding agencies are finding Center-based programs an important research funding vehicle. For example, our Konza Prairie Biological Station's Long-Term Ecological Research Program through the National Science Foundation (NSF) is probably one of the oldest such entities on our campus with continuous and substantial funding since the early 1980's. The Centers of Biomedical Research Excellence (COBRE) awards funded by the National Institutes of Health (NIH) are probably the newest examples and these awards to Kansas State University (K-State), the University of Kansas (KU), and the University of Kansas Medical Center (KUMC) facilitate important interinstitutional collaboration and help build teams that transcend the borders of any single campus. 
Land-grant research universities have valuable strengths: because they are the historical national centers of research on life sciences that relate to plants and animals and the environment, the land-grants have been recruited for important new roles in national security. We have been tapped to help protect the nation's food supply from bioterrorism threats, and the land-grant universities have responded with amazing speed and focus.

The Land Grant Mission of K-State implies a depth and diversity in the types of research that we are have, with mandated emphasis on science, life sciences, mathematics and engineering. That focus continues to prepare landgrant graduates for a host of career path options. Why is basic research so important for our academic enterprises?

First, all universities should focus on basic research, whether it is in molecular biology, material surface chemistry, or particle physics. Today, for example, K-State is the home to a major genome project - the sequencing of the genome of the red flour beetle. This little critter is an important research tool in comparative development and evolutionary genetics, with a practical side as well. It is a major pest of stored grain, and studying this organism within the genome project - the most basic of basic research - falls well within our agricultural mission.

The K-State Department of Physics is home to the Macdonald Laboratory, funded by the Department of Energy, for the study of the basic structure of atoms/matter and the lab is ranked as a national-class program. Again, as an example of the growing trend for different universities to form teams of researchers, I also understand that K-State physicists are forming a partnership with their $\mathrm{KU}$ colleagues to make a run at having the planned $\$ 50$ million Cosmic Ray Observatory be built in western Kansas.

Second, our mandate as a land-grant institution implies that research should have a practical flavor where possible. What we mean by this is simple: our research should have value to the people of the state. For example, we have an international reputation in our Department of Grain Science and Industry. K-State is the only university-based undergraduate education program in flour milling, feed milling, and bakery science. In these industries, we have an unparalleled reputation with food preparation professionals from all over the world who attend advanced training workshops in Manhattan.

Similarly, wheat genetics - and our national Wheat Genetics Research Center - extends a basic genetic approach to studying the most important food crop in Kansas - and possibly in the world for that matter, as wheat is beginning to edge out rice as the most important source of the world's calories. Led by our fourth-ranked Department of Plant Pathology, our genetic approaches have improved yield by increasing wheat plant resistance to insect, bacterial, fungal, and viral damage. The development of new wheat varieties is always a team 
effort at Kansas State University. It involves at the very least agronomists, plant pathologists, entomologists, and cereal chemists. Wheat varieties - like Jagger and 2137 - have been developed at Kansas State University in the past several years to excel in the growing conditions of Kansas and much of Oklahoma and Texas. Kansas is the No. 1 producer of wheat in America and you should know that $80 \%$ of our state's wheat comes from wheat varieties developed at K-State. The President of the Kansas Senate, Dave Kerr, has publicly and recently lauded K-State wheat varieties like Jagger because his wheat fields have produced higher yields with Jagger and 2137 wheat varieties. Dr. Bikram Gill, a world-class wheat scientist, states that K-State's Jagger wheat is not only the No. 1 winter wheat variety in Kansas, but is also grown in the neighboring states of Nebraska and South Dakota to the north and Oklahoma and Texas to the south and many countries in the world, including Turkey, Russia, Eastern Europe, many of the former Southern Soviet Republics, and Latin America.

Third, to be truly useful, research findings have to leave the laboratory quickly and find their way into the economy of Kansas as new products, processes, technologies, and businesses. Our Kansas State University Research Foundation, which holds the intellectual property for the University, was chartered in the early 1940's. This group is responsible for protecting our faculty members' research through patents and copyrights, and works for licenses through the National Institute for Strategic Technology Acquisition and Commercialization. The University, the City of Manhattan, and the State of Kansas through its state entity called KTEC formed a partnership to develop NISTAC, which commercializes not only University Intellectual Property (IP), but also a large portfolio of donated patents as well.

Let me give you several examples of our recent success. The Research Foundation holds several patents from applied research performed by the Grain Science and Industry group. One of those patents, developed by Dr. Paul Seib of the Department of Grain Science and Industry, described a way to treat plantbased starch such that it is not digested by the enzyme amylase - that makes it unavailable to the human body when ingested. Three years ago, the Research Foundation could not even find a licensee for that interesting patent. Then, along came the Atkins Diet, and, now, the Kansas-based company that currently has the license cannot keep up with demand for the low-carb wheat and potato starches for use in food products. We recently honored Dr. Paul Seib for his achievements at an awards banquet in Manhattan.

Another example of an outstanding commercialization success involves chemistry on the nano-scale - that is at the billionth level. Nanoparticles of metal oxides are so small that they do not behave like they do in bulk chemicals. They have the extraordinary characteristic of being able to absorb toxic chemicals and nasty biologicals (such as Anthrax spores and viruses) and detoxify them. After the chemical reaction, the chemicals are benign and the biological organisms are dead. 
The nanoparticles have great potential to neutralize and clean up chemical spills. In an extremely short time, the commercial entity, Nanoscale Materials Incorporated, was established as a start-up company in Manhattan, Kansas. Nanoscale, Inc., now has several products in the marketplace including a FAST-ACT product that is currently being developed at the Aberdeen Proving Ground Fire Department. K-State will be represented at the Olympics in a few weeks, as FAST-ACT will be also deployed in Athens for the 2004 Olympic Games. Through the efforts of our Research Foundation and NISTAC, this intellectual property was patented and brought to market through a series of developmental steps in a business incubator, small stock offerings, and as an anchor member of our new Research Park. The FAST-ACT Nanoscale products are being sold nationally to a multitude of first responders from coast to coast. This is a remarkable example of how research universities can impact regional economies.

This is a great example of focused human curiosity. We call it basic research that proceeded from question to question to question until the scientist involved knew something that humans had not known before.

The K-State chemist by the name of Professor Ken Klabunde discovered essentially a new state of matter. The extremely small particles are incredibly reactive. The early experiments revealed they detoxify many harmful chemicals. Subsequent work revealed a wide-open range of useful possibilities. His insights lead from laboratory work to a general realization that commercial products might be based on these findings. Uses continue to emerge for these potent, detoxifying products that do no harm to the environment.

Still another example of our on-going research came with a donated technology. K-State received a gift of patents and process technology from Procter \& Gamble for a drink that mixes milk and fruit juices and fortifies it with calcium and Vitamin C. Through the efforts of our K-State food scientists in the College of Human Ecology and the Mid-America Commercialization Corporation in Manhattan, a company called NutriJoy was established to develop and market this product. So far, the product is being very successfully marketed on the West Coast and the Midwest. Wal-mart stores and their Sam's Club groceries, for example, are now carrying the delicious Peach Mango Cal-C drink. What we are trying to do here is to develop a seamless method of moving intellectual property, whether developed at the University, donated by corporations, or licensed from others, through the developmental stages into viable commercial products.

Finally, another good example of our success with both basic and applied research comes readily to mind with our new Food Safety and Security program at K-State. In the fall of 1999, long before September 11, 2001, a group of KState scientists and I testified before Senator Pat Roberts' U.S. Senate 
Emerging Threats Subcommittee on the threat from terrorists and rogue nations for America's food supply. We pointed out in October of 1999 the monumental threats that were facing America's entire food system. America has the greatest agri-business and food system in the world and it provides the safest and lowestcost food of any country on the face of the Earth. The American people spend about 9-cents out of every dollar for food. This is what gives the American people the highest standard of living of any nation in the world. If agro-terrorists were successful, for example, in introducing Anthrax to several of our feedlots in southwestern Kansas, this could have enormous and negative repercussions not only for the economy of Kansas, but for the economy of America. Just imagine if, in a short period of time, the American people had to spend 25-cents out of every dollar for food rather than 9-cents and I think you can get the idea of what consequences that would have on our economy.

K-State now has over 100 research scientists in a number of Colleges and Departments working on food safety and security. We have built a national reputation in the field of protecting America's food supply. For example, the National Plant Diagnostic Network at K-State is a key part of our Homeland Security effort to protect agriculture and our Department of Plant Pathology is the regional leader of the Great Plains Region for 9 states. The region's farmers grow $95 \%$ of the nation's sunflowers, $84 \%$ of the sorghum, $73 \%$ of the wheat, $42 \%$ of the cotton, and $35 \%$ of the sugar beets.

Moreover, through the joint efforts of our College of Veterinary Medicine, our Department of Animal Sciences and Industry, our Division of Biology, and our Food Sciences Program, and many other departments, we are combining the scientific expertise that we have at Kansas State University to focus on both intentional and unintentional threats to the nation's food supply. Again, with over 100 research scientists at K-State forming a huge team of researchers on food safety and security, we are in an especially strong position since human health as well as our food supply are threatened by transgenic organisms, such as Anthrax, West Nile Virus, Asian Bird Flu, Ebola, BSE - or Mad Cow Disease and other threats which begin as animal diseases and can also affect humans. Thanks to the foresight of the Kansas Legislature, we are preparing to build a $\$ 52$ million BL3 (Biological Security Level 3) research facility bonded by the State of Kansas. This is the kind of multidisciplinary program that we believe will be very successful in competing for large federal grants and will position Kansas State University as the No. 1 leading land-grant university in food safety and security. We have already been very successful in receiving federal grants, both for the research programs and for the building, and we believe that these successes will continue and increase. A Georgia expert on biosecurity buildings around the world, who is helping to design our new food safety and security building, maintains that this new building will be the most state-of-the-art food safety building in the world and the only food safety building - federal, state, or private - in the world to take in both plants and animals with a food processing floor in the same building. 
I want to switch gears a bit and talk about the leadership challenge from a public education perspective. More and more, state government views its financial commitment to us as only including the classrooms. Legislators seem to view research almost as a kind of hobby, something that faculty members do just to amuse themselves. In their view, our faculty could more efficiently handle larger teaching loads given the increases in tuition that we have all suffered (or had to impose) on our campuses. Even giving them the indicators of the economic impact of research is often not enough to sway the argument.

I believe just the opposite, that research is all about the future; and I trust that, for each of you, the hairs on the back of your neck stand up a bit when this topic is raised. Gary Burtless and Roger Noll, writing in the 1998 book Challenges to Research Universities, underscore a point that we see over and over again. Research adds value to education. And it adds value to our respective states. At K-State, with a relatively modest amount of State funding, our research efforts add about $\$ 3$ billion in economic development monies annually to the state of Kansas - which puts K-State up with our state's largest corporations in terms of its impact on the state.

For graduate-level research, the point should be obvious. Despite the fact that many in our legislatures really do not understand any need for education beyond the bachelor's degree except for a degree in law or the MBA. Research and graduate education are sides of the same coin, and I will not belabor this contention any further.

The research university adds value to an undergraduate degree, and that is a point we need to constantly underscore. As Burtless and Noll phrase it, "the key issue in evaluating educational aspects of research universities is whether education and research are complementary." Of course, they are that and more. Successful researchers obtain grants and publish peer-reviewed books and articles, and, in doing so, they work at the frontier of knowledge. The best education we can offer a student is to steep them in current knowledge, the "what's happening now" in any field - knowledge not limited to a textbook.

Students benefit when they can learn by participating in a laboratory setting and it clearly enhances their understanding of the basic discipline. When this happens, we have doubled the use of our resources - we have made the research infrastructure also the educational infrastructure. Our students have the opportunity to work with new technologies that cannot even be on the radar screens of students at institutions without a research mission. In fact, many of our top undergraduate students mention their hands-on research as the most exciting part of their educational experience at K-State - in addition to the financial support they receive. 
Dr. Coleman's colleague at the University of Michigan, Provost Paul Courant, offers a crystal clear rationale for the imperative to prepare students to have diverse problem-solving skills: "Because we don't know what the next problem is going to be. One of Michigan's biology faculty recently suggested that that is the argument for basic research. It's the best one-line explanation for both basic research and liberal education that I have ever heard." To Provost Courant's thinking, I would add that it is an outstanding rationale for fusing undergraduate education with scholarship in all disciplines - not just "big science."

K-State, being a student-centered research university, has shown real academic success in demonstrating how students, who have become research and laboratory assistants in their freshmen and sophomore years in departments like biology, chemistry, physics, and many other departments, have a definite edge in applying for the nation's most prestigious academic scholarships. For at least the last 15 years or more at K-State, we have tried to get as many of our best and brightest students into various research projects as soon as the first semester of their freshman year. Many of those students have gone on to win a very high number of Rhodes, Marshall, Truman, Goldwater, and Udall Scholarships during the years that I have been President at Kansas State starting in 1986 until the present.

For example, the Goldwater Scholarship is awarded to promising students in the sciences and math. K-State students have won 49 Goldwater Scholarships since that program started - more than any public university in America. K-State students have won 27 Truman Scholarships since that program started - more than any other public university in America. From 1986 to the present, K-State has had 97 students win the Rhodes, Marshall, Truman, Goldwater, and Udall Scholarships and that is 23 more than any other of the 500 public universities in the nation. Penn State students have won 74 of these five academic scholarships. We actually won more of these five prestigious scholarships than MIT or the University of Chicago. Much of our success is due to the fact that we not only get students involved in various research efforts as undergraduates, but also, they receive very good advising.

I want to close with an anecdote that demonstrates the importance of student involvement in the world of research. This example involves a young woman from a small town in Kansas. She recently graduated from K-State and is currently in law school, studying intellectual property law. While on her passage through K-State, she was awarded one of the Goldwater Scholarships that I just mentioned.

Her first visit to K-State was during the summer before her freshman year, when she came to campus to learn about the K-State bachelors in biology. She and her father sat across the desk from the biology advisor, and she pointedly 
admitted that her visit was only as a courtesy to her dad - she had been accepted into Cal Tech, and that is where she wanted to go. Period. The end.

As part of the visit, the biology advisor took her on a tour and showed her a research laboratory. She sat down, and the professor showed her how to work the fairly expensive microscope. On its stage, she was looking at those red flour beetles that I told you about earlier as one of the few genome projects in the state. In that microscope, she was comparing the appearance of normal beetles with others that were developmental mutants.

She looked up skeptically, and asked, "How long would I have to wait before I could have a project like this in here?" The answer from the professor: "Could you start next week?" And, five minutes later, that future Cal Tech student switched to K-State because Cal Tech does not let freshmen do work in laboratories. No exceptions.

One other example of note is an undergraduate student by the name of Rachel Eddy from Western Kansas, who is a National Merit Scholar and true freshman. She is right now conducting cutting-edge research in Wheat Genetics in Professor Bikram Gill's lab under a Howard Hughes Fellowship. She is able to interact with a steady stream of international geneticists who visit the KSU Wheat Genetics Research Center during the year.

K-State's mantra to undergraduates is "opportunity, opportunity, opportunity." If the students want to get their hands and minds wrapped around a research puzzle, we give them every chance to join research teams right away.

Burtless and Noll summarized very well what research universities like KState offer each and every student: "The key point is that attending a research university is privately worthwhile if it provides a good return on the student's investment."

Clearly, a central leadership challenge for public research universities is how we creatively move our research enterprises to new levels, while enhancing the learning environment for students. Through my comments today, I hope that I have given you some examples of how we are trying to meet this challenge at Kansas State University. 